\title{
POLÍTICA EDUCACIONAL E ESTRATÉGIAS DISCURSIVAS SOBRE NACIONALISMO NOS PLANOS NACIONAIS DE DESENVOLVIMENTO (1970-1985)
}

\begin{tabular}{c}
\hline EDUCATIONAL POLICY AND DISCURSIVE STRATEGIES ON NATIONALISM IN NATIONAL \\
DEVELOPMENT PLANS (1970-1985) \\
\hline POLÍTICA EDUCATIVA Y ESTRATEGIAS DISCURSIVAS SOBRE NACIONALISMO EN LOS \\
PLANES NACIONALES DE DESARROLLO (1970-1985)
\end{tabular}

\section{Rosângela Maria de Nazaré Barbosa e Silva}

\begin{abstract}
RESUMO: Este texto tem por objetivo estabelecer relações sobre as estratégias discursivas dos documentos educacionais, a partir dos planos nacionais de desenvolvimento do Regime Militar. Para tal, devemos considerar as especificidades e características do contexto nacional em que foram realizadas as reformas educacionais. Tratava-se de uma sociedade capitalista, inserida de forma periférica no mercado mundial. Ponderamos que tanto o modelo econômico como a conjuntura imposta pela ditadura de segurança nacional tiveram influência no direcionamento e na forma da política educacional a partir de 1964 e, consequentemente, nas reformas educacionais para a educação superior. Esse processo sofreu influência de grupos sociais organizados e vários outros segmentos da sociedade que polarizaram as atenções de planejadores e estudiosos da educação. Apesar das tensões ensejadas, existia um relativo consenso que se tornava comum, entre os diferentes agentes sociais, uma estratégia discursiva baseada no nacionalismo e na modernização do Brasil que, por vezes atravessariam os projetos educacionais e de desenvolvimento.
\end{abstract}

PALAVRAS-ChaVE: Política educacional. Nacionalismo. Planos nacionais. Estratégias discursivas.

ABSTRACT: The purpose of this text is to establish relations on the discursive strategies of educational documents, based on the national plans for the development of the Military Regime. To this end, we must consider the specificities and characteristics of the national context in which educational reforms were carried out. It was a capitalist society, inserted peripherally in the world market. We point out that both the economic model and the conjuncture imposed by the national security dictatorship had an influence on the direction and form of educational policy since 1964 and, consequently, on the educational reforms for higher education. This process was influenced by organized social groups and various other segments of society that polarized the attentions of educational planners and scholars. Despite the tensions, there was a relative consensus among the different social agents, a discursive strategy based on nationalism and the modernization of Brazil that would sometimes cross educational and development projects.

KEYWORDS: Educational policy. Nationalism. National plans. Discursive strategies.

RESUMEN: Este texto tiene por objetivo establecer relaciones sobre las estrategias discursivas de los documentos educativos, a partir de los planes nacionales de desarrollo del Régimen Militar. Para ello, debemos considerar las especificidades y características del contexto nacional en que se realizaron las reformas educativas. Se trataba de una sociedad capitalista, inserta de forma periférica en el mercado mundial. Ponderamos que tanto el modelo económico como la coyuntura impuesta por la dictadura de seguridad nacional tuvo influencia en el direccionamiento y en la forma de la política educativa a partir de 1964 y, consecuentemente, en las reformas

Submetido em: 01/06/2017 - Aceito em: 30/06/2017 - Publicado em: 13/09/2017.

\begin{tabular}{l|c|c|c|c|c} 
(C) Rev. Inter. Educ. Sup. & Campinas, SP & v.3 & n.3 & p.678-705 & set./dez. 2017 \\
\hline
\end{tabular}


educativas para la educación superior. Este proceso sufrió una influencia de grupos sociales organizados y varios otros segmentos de la sociedad que polarizaron la atención de los planificadores y estudiosos de la educación. A pesar de las tensiones que existían, existía un relativo consenso que se hacía común entre los diferentes agentes sociales una estrategia discursiva basada en el nacionalismo y la modernización de Brasil que a veces atravesar los proyectos educativos y de desarrollo.

PALABRAS ClAVE: Política educativa. Nacionalismo. Planes nacionales. Estrategias discursivas.

\section{INTRODUÇÃO}

Neste estudo sobre a estratégia discursiva ${ }^{2}$ presentes nos textos educacionais acerca da política educacional, identidade nacional, nacionalismo e relações "raciais"3 no estado do Pará, fizemos a escolha de algumas texturas que compunham os tempos da Ditadura Militar no Brasil e construímos uma trama. Essas texturas de uma política educacional desenvolvimentista estão fundamentadas em três palavras: nacionalismo, identidade nacional, educação.

Essa trilogia se junta dentro de um momento em que era imperiosa a necessidade de difundir e ampliar cada vez mais a campanha da instrução pública como fator evidente de progresso do povo na Amazônia, bem como da implantação de projeto militar de povoamento, mas não somente isso ${ }^{4}$. Essas influências, tanto políticas quanto desenvolvimentistas e modernizadoras, também foram percebidas na educação paraense, pois conforme alerta Coelho (2008, p.110), “o conteúdo pedagógico, assim, esteve sempre associado ao imperativo econômico".

Certamente, vários planos de desenvolvimento econômico nacional foram aprovados nos anos 1970, os quais tiveram especial influência na Amazônia, cabe destacar o Plano de Integração Nacional (PIN), de junho de 1970, que tinha como meta principal financiar as obras de infraestrutura destinadas a facilitar o desenvolvimento de atividades econômicas na área de atuação da SUDAM, entre elas a construção da Transamazônica e a Belém-Brasília e os Planos de Desenvolvimento da Amazônia, período de 1972-1974, e de 1975-1979.

O Plano de Desenvolvimento da Amazônia - PDA para o período de 1972-1974 anunciava que as conquistas essenciais, quanto à Amazônia, propostas pelo governo federal, referiam-se

\footnotetext{
2 Esta é uma noção trabalhada por Bourdieu (2004, p. 81) que a compreende como “[...] o instrumento de uma ruptura com o ponto de vista objetivista e com a ação sem agente, suposta pelo estruturalismo (que recorre por exemplo à noção de inconsciente) [...] Ela é produto do sentido prático". Conotando "sequências de práticas estruturadas" que os agentes desenvolvem em função de habitus adquirido e das possibilidades de um determinado campo para obtenção do "sentido do jogo" social.

${ }^{3}$ Sobre o termo "racial" aspeado ver as discussões de Schwarcz (2012a; 2012b). Nestas obras a autora esclarece que o termo "raça" com aspas assume o argumento político de um conceito operante na sociedade brasileira.

${ }^{4}$ Ver PETIT, Pere; CUÉLLAR, Jaime. O Golpe de 1964 e a instauração da ditadura civil-militar no Pará: apoio e resistências. Revista Estudos Históricos, Rio de Janeiro, vol. 25, nº 49, p. 169-189, jan-jun de 2012.
} 
à utilização de uma "estratégia que promova o progresso de novas áreas e a ocupação de espaços vazios" e à "integração do desenvolvimento do Nordeste com a estratégia da ocupação econômica da Amazônia" (BRASIL/SUDAM, 1971, p. 13).

No II PDA, período de 1975-1979, os objetivos do I PND (1972-1974) eram sintetizados; entretanto, não podemos esquecer que estamos nos últimos anos do denominado milagre brasileiro, cujo desfecho deve ser creditado ao crescimento das atividades econômicas de que dispunha a Amazônia em relação a outras regiões do país, de modo a contribuir ao desenvolvimento econômico nacional. Quanto à questão educacional, o II PDA menciona que a implantação do novo sistema educacional tem sido lenta e difícil e que:

Na Amazônia, via de regra, os obstáculos à reforma tendem a ser maiores, uma vez que o setor educacional apresenta problemas de natureza complexa e interdependentes, por se constituírem numa relação de causa/efeito do sistema socioeconômico, bem como do quadro demográfico regional [...] os principais problemas situam-se na área de atendimento escolar, onde grande parte da população escolarizável, em todos os níveis, ainda se encontra fora das escolas, tornando ainda expressiva a taxa de analfabetismo e na produtividade do ensino, onde a qualificação insuficiente do corpo docente, a carência de especialistas, a inadequação de currículos, a evasão e a repetência se apresentam como obstáculos fundamentais (BRASIL/SUDAM, 1976, p. 21-22).

Esses projetos favoreceram a expansão populacional e consequentemente a difusão e circulação de práticas modernizadoras e desenvolvimentistas. Criaram expectativas de mudanças sociais e econômicas entre os colonos e demais moradores da região. Entre os colonos, essa possibilidade de melhores condições de vida estimulou a mobilização para as áreas de colonização, e entre os Militares, alimentou o discurso de alcançar mais uma fronteira (PETIT, 1996; 2003). A política educacional, nesse sentido, pode ser analisada como mediadora na relação entre os colonos e os agentes do Estado, que viam com bons olhos os projetos propostos pelos Governos Militares, conforme nos indica Lima (1973) em discurso proferido no II Encontro de Educadores na Amazônia ${ }^{5}$.

Os maiores aplausos merecem essas entidades, que se abrem para facilitar a tarefa de educação na Amazônia, como aplausos merecem esses educadores que, incansáveis, recorrem à comunidade para dar a educação que o momento exige, para o engrandecimento socioeconômico da área (LIMA, 1973, p. 175 - grifo nosso).

Dada à configuração dessa realidade, a Política de Educação do Estado do Pará sempre esteve atrelada às diretrizes políticas e econômicas do Estado, no intuito de viabilizar uma proposta desenvolvimentista.

${ }^{5}$ Conferência proferida pelo Prof. Antônio Vizeu da Costa Lima, no II Encontro de Educadores na Amazônia, realizado em Manaus, no período de 23 a 27 de julho de 1973. In: Revista de Cultura do Pará, Ano 3, nº 12 e 13 ,jul/dez, 1973, p. 156-175.

(C) Rev. Inter. Educ. Sup.

Campinas, SP $\quad$ v.3

n.3 p.678-705 set./dez. 2017 
Com esta noção, pretendemos destacar que as políticas educacionais paraenses no período compreendido de 1970-1985, são implementadas num espaço social estruturado e perpassadas por diferentes interesses e resistências, e ainda, supomos o quanto esta estrutura educacional é estruturante, no dizer de Bourdieu (1990), de políticas educacionais que perduram até os dias atuais. Especificamente, em que medida a categoria nacionalismo, enquanto noção mediadora para a investigação do campo educacional possibilitaria ampliar a compreensão de que uma concepção de nação pretendida pelo Regime Militar omitia diferentes identidades históricas?

Bourdieu trabalha com a configuração do campo social como a conjugação do setor político, econômico, cultural e educacional reconhecendo que:

A tensão entre as posições, constitutiva da estrutura do campo, é também o que determina sua mudança, através de lutas a propósito de alvos que são eles próprios produzidos por essas lutas; mas, por maior que seja a autonomia do campo, o resultado dessas lutas nunca é completamente independente de fatores externos (BOURDIEU, 2010, p. 65).

Acompanhando, então, a reflexão de Bourdieu, para a leitura do campo educacional desde a educação básica à superior, entendemos que a formulação e implantação das políticas direcionadas para a educação adquirem características semelhantes à elaboração das demais políticas públicas, sofrendo as disputas de grupos sociais que defendem interesses antagônicos. Apesar de serem debatidas por diversos setores sociais, as políticas públicas para a educação enquadram-se nas plataformas de ações determinadas pelos governos que as adotam, nem sempre, condizendo com as aspirações da maioria da população. A busca e a defesa de determinados modelos educacionais por alguns setores da sociedade e o não atendimento dessas reivindicações por parte dos governos, eventualmente, geram manifestações de contrariedade e protestos, tornando a educação um campo social de disputas e interesses permanentes, onde o "sentido imediato do mundo" é, em grande medida, imposto (BOURDIEU, 2000).

\section{ESTRATÉgIAS DISCURSIVAS SOBRE NACIONALISMO NOS PLANOS NACIONAIS DE DESENVOLVIMENTO}

O período que precedeu a Lei $\mathrm{n}^{\circ} 4.024 / 1961$ se caracterizou por intensos debates sobre a democratização do ensino e mobilizou amplos setores da sociedade em defesa da escola pública. Foi um período marcado pela concepção do planejamento nas ações estatais (OLIVEIRA, 2000). O planejamento educacional constituía um dos focos da divergência. E ainda, nessa época, o nacionalismo assume uma nova expressão: o desenvolvimentismo.

De tal modo que, o planejamento no Brasil substancia-se com o Governo de Kubitschek, por meio do Plano Nacional de Desenvolvimento, conhecido como Plano de Metas e estabelecido por aquele governo a partir de diagnósticos realizados pelo Banco Nacional de

\begin{tabular}{l|l|l|l|l|l} 
(c) Rev. Inter. Educ. Sup. & Campinas, SP & v.3 & n.3 & p.678-705 & set./dez. 2017 \\
\hline
\end{tabular}


Desenvolvimento Econômico - BNDE e da Comissão Econômica para a América Latina e Caribe - CEPAL e da Escola Superior de Guerra - ESG (DREIFUSS, 1981, p. 75). O diagnóstico apontava os "pontos de estrangulamentos" da economia brasileira, cujas metas, em número de trinta, deveriam ser implantadas em cinco anos, correspondentes ao mandato presidencial, e estavam divididas em cinco setores-chave: energia, transporte, indústria de base, alimentação e educação ${ }^{6}$. Esses setores eram voltados para a superação desses "obstáculos estruturais".

Assim como Dreifuss, Ianni (1991, p. 43), também, identifica no período focalizado o surgimento da planificação econômica como uma prática no pensamento governamental brasileiro. O planejamento, na visão do autor, surge como uma técnica "mais racional" de organização das informações, análise de problemas, tomada de decisões e controle da execução de políticas econômico-financeiras, tal como o pretendido no programa de JK. O planejamento foi então assimilado, segundo Oliveira (2000, p. 197), como "necessário e indispensável ao desenvolvimento social”.

A educação, nesse sentido, é compreendida como um instrumento para promover o crescimento e reduzir a pobreza, bem como, conforme suscita Oliveira (2000, p. 197) "um instrumento econômico indispensável ao desenvolvimento, ao progresso".

O binômio educação e desenvolvimento fez parte dos planos elaborados à época em questão, justamente o auge da doutrinação cívica e da repressão. Como meio de controle social, enfatizaram a "revolução pela educação" e determinaram os objetivos nacionais a serem alcançados na persecução do desenvolvimento. Nessa perspectiva, a política educacional passou a ser pensada como integrante dos planos econômicos globais e, como política pública, voltou-se "para atuar na correlação de forças sociais, seguindo as determinações daquele desenvolvimento" (VIEIRA, 1985, p. 10).

Entretanto, durante o governo parlamentarista de João Goulart, é preparado o Plano Trienal de Educação, para o período de 1963 a 1965. Cumpre destacar que o plano educacional é parte integrante do Plano Trienal de Desenvolvimento, elaborado pelo então Ministro Extraordinário de Planejamento Celso Furtado (Decreto nº 1.422 de 27/09/1962). O Plano foi criado com os objetivos básicos de promover um desenvolvimento econômico rápido e apontar novas perspectivas de superação para os problemas econômicos. Ele traduzia esses interesses e apresentava as diretrizes gerais para o desenvolvimento econômico. Isso estava

\footnotetext{
${ }^{6}$ Os três primeiros setores foram os mais favorecidos. O setor de energia tinha cinco metas; o de transporte, sete; de indústria de base, onze; de alimentação, seis; e de educação, apenas uma. Além destas, havia ainda a chamada meta-síntese, a construção de Brasília ( $31^{\text {a }}$ meta).
} 
determinado desde o título dado: Pré-investimento para aperfeiçoamento do fator humano (BRASIL, 1966, p. 05).

Suas diretrizes gerais apontavam para aspectos sobre o ensino primário, médio, superior, contemplando a expansão de matrículas, formação de docentes, construção de prédios com estabelecimento de previsão de recursos. Face ao diagnóstico anteriormente mencionado, na introdução das diretrizes gerais do programa, o Plano referia-se:

Em face da realidade apresentada, o programa que adiante se propõe de expansão e aperfeiçoamento dos serviços escolares brasileiros é, apesar de possíveis aparências em contrário, o mais modesto que se poderia organizar, em face do grave retardamento em que nos achamos com relação ao desenvolvimento dos recursos humanos da sociedade brasileira (BRASIL, 1966, p. 13).

A despeito de o Plano Trienal ter sido elaborado em um contexto internacional favorável, proporcionado pela Carta de Punta del Este, de 1961, de investimentos externos com apoio e incentivos norte-americanos para os programas de desenvolvimento econômico em relação à America Latina, segundo as reformas de base que precisariam ocorrer em nível internacional e frente à crise de liderança desencadeada pela Revolução Cubana. As propostas de desenvolvimento tensionavam entre os grupos que postulavam a expansão do capitalismo "interdependente" e os adeptos do capitalismo "nacional", defensores do protecionismo (IANNI, 1991). As tensões político-sociais aumentaram com a crescente politização das massas urbanas e a radicalização das posições de direita e esquerda (ROMANELLI, 1994, p.193).

As mudanças no âmbito educacional que o Plano Trienal se propunha realizar interligavam-se com as reformas estruturais. Conforme Mensagem enviada ao Congresso Nacional, o presidente Goulart, em março de 1963, assegura: "Não obstante, o próprio resultado do Plano Trienal está, em boa medida, dependente da eficácia das reformas de base, que afinal vierem a ser instituídas pelo Congresso Nacional" (BRASIL, 1964, p. 19). As reformas sugeridas no Plano, tais como Reforma Administrativa, Fiscal, Agrária e Habitacional, necessárias para seu sucesso, não conseguiram ser implementadas pelo Governo Goulart, por serem bastante indefinidas, servindo ao proselitismo político. Entretanto, a necessidade de mudanças estruturais parece se confirmar posteriormente quando, em parte, foram executadas pelos governos posteriores.

Nesse aspecto, Skidmore (1988, p. 37-44) menciona que, diante das dificuldades econômicas, o governo de Goulart adotou uma nova opção de nacionalismo, o "nacionalismo radical". Essa corrente afirmava que "o setor externo da economia era a causa das graves dificuldades do país". Então, o governo impôs um controle rigoroso das empresas estrangeiras e remessa de lucros. Passou-se a disseminar estratégias discursivas não só por parte do Estado, mas 
também por um movimento político e ideológico da sociedade, preocupada em atingir e mobilizar o maior número dentro dos partidos, sindicatos e associações de intelectuais, estudantes e militares que aderiram ao nacionalismo, definindo-o como uma ideologia indispensável à prática política preocupada e comprometida com o desenvolvimento econômico nacional, independente e autossustentado. Por isso, a partir de 1963, Goulart passou a defender "com crescente entusiasmo um conjunto de "reformas de base" que incluiriam reforma agrária, educação, impostos e habitação".

A esse respeito, Guibernau i Berdun (1997, p.81) menciona que cada vez que um governo adota um tipo de nacionalismo "há um grande interesse em controlar a educação, em publicizar e utilizar os vernáculos, assim como em salientar os traços e símbolos [...] para alcançar as massas". Outro autor que corrobora essa assertiva é Habermas (2000, p. 304), para o qual o nacionalismo do século XX "serviu de instrumento para garantir a mobilização das massas em favor de políticas diante das quais a oposição, se não a resistência, teria sido o curso de ação acertado".

$\mathrm{Na}$ verdade, tal forma de pensar a construção da nação, adotada pelo governo brasileiro, fundamentava-se em interesses nitidamente econômicos ou, mais precisamente, industrialistas. De acordo com Hobsbawm (2002, p. 41) essa era uma concepção muito próxima do modelo nacionalista alemão do século XIX, que identificava o Estado-Nação como um espaço físico e humano capaz de dar sustentação ao desenvolvimento capitalista, pois "todas estas medidas intencionavam desenvolver o germe da nacionalidade" e, ainda, "esse desenvolvimento tomaria forma de uma industrialização capitalista levada adiante por uma burguesia vigorosa" (idem, p. 42).

Para esse tipo de nacionalismo adotado pelo governo brasileiro, os possíveis "inimigos internos e externos" não se determinam por diferenças culturais, étnicas, linguísticas ou religiosas, mas de caráter fundamentalmente econômico, o qual exige do Estado uma posição a respeito do desenvolvimento industrial, bem como proteção contra a competição estrangeira que ameaçaria o pleno desenvolvimento nacional. Nesta perspectiva, os movimentos negros que nesse período articulavam protestos contra o racismo torna-se-iam obstáculos aos Objetivos Nacionais de "integração nacional" e ameaçariam a "paz social", ao desnudar a "desintegração" da sociedade brasileira. De acordo com Skidmore (2001, p. 138) o "governo militar frequentemente intervinha para suprimir notícias que contradissessem a imagem oficial de harmonia racial".

Esse posicionamento significava que era necessário evitar, qualquer incoerência do conjunto, de maneira a garantir a inexistência de conflito entre objetivos divergentes no tocante às questões raciais, o que impediria o alcance das metas desenvolvimentistas. 
Após o golpe civil-militar, na tentativa de construir um plano mais abrangente e de longo prazo, surgiu o Plano Decenal de Desenvolvimento Econômico e Social (1966-1976), consubstanciado por diagnósticos preliminares em vários setores, e tendo como ponto de partida a "compatibilidade com o esquema macroeconômico" (EPEA', junho/1966, p. 20), de modo a elaborar uma estratégia global que direcionasse o progresso, bem como o planejamento em todos os âmbitos do país.

Dada as especificações do Plano Geral dos Diagnósticos, elaborado pelo Ministério do Planejamento, para o período de 1966-1976, com vias a localizar com maior precisão, os problemas que dificultavam o desenvolvimento nacional, procedeu-se diagnósticos nos setores denominados de a) infraestrutura: Energia elétrica; petróleo, carvão; transportes e comunicações; b) agricultura e abastecimento; c) indústria e mineração; d) serviços: turismo, comércio, intermediários financeiros; e) sociais: educação e mão de obra; saúde e saneamento; habitação; previdência social; f) regionais: sistema norte; sistema nordeste e sistema centro-sul.

Nas palavras do presidente Castello Branco, na Solenidade de instalação dos Grupos de Coordenação, criados em 1966, com fito de coletar informações básicas, corporificadas depois nos documentos preliminares para os diversos setores dentro do plano global, objetivase:

[...] aumentar o grau de eficácia e racionalidade da política econômica [...] A despeito da universalidade da prática do planejamento, independente dos regimes políticos e do nível de desenvolvimento dos países que o praticam, e sem embargo de sua generalizada aceitação, no Brasil, nas mais diversas formas de atividades, a verdade é que a sua exata significação ainda não é geralmente compreendida [...] por outro lado, cumpre atentar detidamente para o impacto que a educação e os demais setores de caráter social podem produzir sobre o desenvolvimento econômico nacional (EPEA, 1966, p. 21-24).

A política educacional desenvolvimentista articulou-se, segundo Shiroma e outros (2004), a uma significativa reorganização do Estado em vista dos objetivos que deveria efetivar para atender os interesses econômicos vigentes. Essa perspectiva, em relação à educação, é confirmada no Plano Decenal de Desenvolvimento Econômico e Social (1966-1976), para o qual a educação deveria assegurar "a consolidação da estrutura de capital humano do país, de modo a acelerar o processo de desenvolvimento econômico" (EPEA, set. 1966, p. 180).

Vale destacar também que, no referido documento, a educação era compreendida como uma “indústria de prestação de serviços” (EPEA, jun. 1966, p. 31). O critério utilizado para

\footnotetext{
${ }^{7}$ O EPEA - Escritório de Planejamento Econômico e Social do Estado, foi durante os anos iniciais do Regime Militar transformado no Instituto de Planejamento Econômico e Social Aplicado - IPEA, sob a supervisão de Mário Henrique Simonsen. Esse Instituto foi estabelecido para realizar estudos, pesquisas e análises nas esferas econômica e social solicitadas pelo Ministério do Planejamento (DREIFUSS, 1981, p. 427).

\begin{tabular}{l|l|l|l|l|l} 
(C) Rev. Inter. Educ. Sup. & Campinas, SP & v.3 & n.3 & p.678-705 & set./dez. 2017
\end{tabular}
}


produzir essa afirmativa derivava da capacidade do mercado de trabalho de assimilar os indivíduos diplomados pelo sistema escolar, bem como estava relacionada à eliminação da capacidade ociosa, identificada em termos de instalações físicas e recursos humanos (idem, p. 33). Ademais, a educação compreendida de forma técnica, começou a ocupar um papel de destaque no discurso presente no planejamento nacional.

Com relação a esses aspectos, durante o governo militar, difundiu-se por meio das estratégias discursivas do complexo IPES ${ }^{8} / \mathrm{IBAD} / \mathrm{ESG}$ a crença na "neutralidade do regime", enfatizando-se o seu caráter "tecnocrático" pela interação "natural" dos chamados técnicos com os militares, reforçando o sentimento de que a abordagem dos problemas do Brasil e a natureza das diretrizes governamentais para solucioná-los eram "científicas" e "nacionais" ao invés de políticas (DREIFUSS, 1981, p. 418-419).

Ainda segundo Dreifuss (1981, p. 442), a política educacional do regime militar "tornou-se a expressão da "reordenação das formas de controle social e político"" necessária aos interesses econômicos vigentes. $\mathrm{O}$ autor assinala a preocupação com "a mão de obra mais qualificada para os escalões mais altos da administração e da indústria" e, ainda, que a tendência à especialização no ensino superior, evidenciada no planejamento da educação, deve ser compreendida em seu contexto de origem, ou seja, em uma economia "cujo funcionamento calcado numa tecnologia sofisticada, importada e que produz bens de consumo duráveis para uma minoria da população", a qual requer, na verdade, "recursos humanos especializados e qualificados, mas em pequenos números".

No Plano, duas formulações são ressaltadas em seus objetivos primordiais, de um lado, salienta a importância do fator educação no processo de desenvolvimento econômico e social. E, de outro lado, visa contribuir de algum modo para o melhor esclarecimento da estrutura e problemas do sistema educacional brasileiro (idem, p. 49). Desse modo, ficam expressas as formulações discursivas para aquele momento histórico, conforme os interesses dos grupos sociais a ele alinhados.

\footnotetext{
${ }^{8}$ IPES - Instituto de Pesquisa Econômica e Social, criado por líderes empresariais cariocas e paulistas, tendo à frente o General da reserva Golbery do Couto e Silva. Estes tinham a tarefa de ajudar a constituir e consolidar legitimidade para o Governo Militar, fundamentando-se na ideia-chave de desenvolvimento nacional. Segundo Dreifuss (1981, p. 296) o IPES financiou e abasteceu de material de propaganda diferentes entidades e desenvolveu sua própria campanha para Educação Cívica, com o objetivo de "despertar a consciência cívica da nação e o estímulo patriótico à grande massa, principalmente, a classe média, os trabalhadores e a juventude". $\mathrm{O}$ Instituto Brasileiro de Ação Democrática - IBAD, associação de empresários, de perfil anticomunista, cujo objetivo era intervir diretamente na vida política. Dreifuss mostrou, em seu estudo, que o complexo IPES/IBAD atuava de maneira bastante variada, em diversas frentes, como a que aqui indicamos, mobilizando grupos diversos, espraiando-se por todo o país e amparando-se em recursos e financiamentos razoavelmente abundantes (idem, p. 259).
}

\begin{tabular}{|l|l|l|l|l|l|}
\hline (C) Rev. Inter. Educ. Sup. & Campinas, SP & v.3 & n.3 & p.678-705 & set./dez. 2017 \\
\hline
\end{tabular}


Nesse sentido, o Estado de Segurança Nacional e Desenvolvimento traçou uma política educacional que encobrisse todo o sistema educacional do país, inclusive na educação superior. Os princípios de eficiência, flexibilidade, modernização, racionalidade e subordinação ao modelo econômico foram sempre os eixos para as medidas adotadas. Em paralelo, fez-se fortíssima repressão a toda sociedade e "difundiu-se amplamente a ideologia de que a educação é uma solução para os problemas nacionais" (SANFELICE, 2011, p. 331).

Desse modo, é no plano das interferências exercidas pelo Governo Ditatorial nas políticas endereçadas à educação que se pode constatar com maior evidência, a forma como aquele procura conduzir a implementação e o desenvolvimento dos programas educacionais de seu interesse, por meio de seus planos globais, os quais são tomados como pontos prioritários para operacionalizar o sistema produtivo, tais como: Plano Decenal de Desenvolvimento Econômico e Social (1966-1976) e Plano Setorial de Educação e Cultura (1972-1974).

Freitag (1986, p. 100) também corrobora a compreensão, quando nos informa que, a despeito do Plano Decenal de Desenvolvimento Econômico e Social nunca ter sido traduzido em termos de projetos e programas de implantação, nele se encontra, de forma explícita, o conceito econômico de educação, ou de modo mais específico, a contribuição desta para o desenvolvimento. A autora argumenta que o enfoque econômico já estava presente no diagnóstico preliminar ao Plano, que abrangeu "todos os setores a serem afetados pelo planejamento, inclusive o educacional". Entretanto, destaca:

\begin{abstract}
A previsão de recursos humanos necessitados em 1976 levou à formulação de quatros planos específicos (o de formação de mão de obra industrial, formação de mão de obra rural, planos para os ramos de ensino superior relativos à formação de profissionais em ciências médicas, plano de formação e treinamento do magistério primário). O plano decenal referente à formação de recursos humanos e educação termina fazendo proposições para a "ação federal no setor educacional". Prescreve basicamente os orçamentos que o governo federal deve pôr à disposição do setor, para realizar os objetivos gerais e específicos formulados (FREITAG, 1986, p. 101).
\end{abstract}

Constata-se, nesse plano, haver no conjunto de ideias e propostas de ações à participação do setor público no sistema educacional, a qual deve, por todos os meios, ser incentivada, especialmente no Ensino Superior, e, acima de tudo, estruturada de modo a democratizar a educação brasileira e a torná-la "vigoroso instrumento de progresso, como o tem sido nos países mais prósperos do mundo moderno" (EPEA, setembro/1966, p. 59). Não deixou, entretanto, o Diagnóstico, de ressalvar a importância política e social do ensino privado, para o qual pediu também os incentivos e ajudas do Estado (idem, ibidem). Fica, assim, explícita uma dada concepção econômica da educação, evidenciando a sua importância para formar a "mão de obra" necessária à concepção de desenvolvimento nacional (idem, p. 256). Ademais, 
Do esforço educacional que o País fizer no sentido de dotar os diversos tipos ocupacionais de mão de obra de perfis educativos mais adequados, é que dependerá poder-se atingir os níveis de desenvolvimento econômico desejados (EPEA, jun. 1966, p. 154).

Essa foi uma das razões que levaram os autores do Plano Decenal de Desenvolvimento Econômico e Social/ Diagnóstico Preliminar - Educação I (BRASIL, 1966, p.17) a considerar em suas estratégias discursivas que "em decorrência da insuficiência das informações disponíveis sobre o estado atual da mão de obra nacional e sua utilização" seria necessário promover formação interna de recursos humanos, pois "a educação ganha significado de investimento quando o fluxo de atendimento e preparação escolar está relacionado com o processo de absorção de mão de obra, na vida produtiva nacional" (p. 33). Entretanto, diagnosticando os diferentes níveis educacionais, os formuladores do Plano Decenal argumentavam que o ensino primário já apresentava uma relativa democratização, apesar de persistirem elevados índices de deserção escolar e insuficiente escolarização, sobretudo nas regiões rurais de baixa densidade demográfica e renda. Quanto ao Ensino Médio, constituía em "ponto de estrangulamento" devido a pouca disseminação da gratuidade e a ativação dos adolescentes para o incremento financeiro de suas famílias, aliada a uma educação que "não implica em melhoria imediata da capacidade de ganhar a vida" resultaram em uma "exagerada seletividade" (p. 49-50) na educação média e superior.

Essa concepção, sem dúvida, expressa o alerta feito por Freitag (1986, p. 68), de que a "seletividade da escola demonstrou sua vinculação à situação de classe dos alunos, também a canalização dos mesmos o é. A opção por diferentes cursos (mais ou menos profissionalizantes) em nível médio e superior não é uma livre opção, mas imposta pela condição de classe".

Essa "exagerada seletividade" estava relacionada com outra estratégia discursiva adotada pelos autores do Plano Decenal, que diz respeito à produtividade no sistema educacional, definida como "a comparação que se estabelece entre resultados realmente obtidos e resultados potencialmente obteníveis para dado conjunto de meios disponíveis e utilizados" (EPEA, jun. 1966, p. 109). Para aferi-la, foram considerados três indicadores: "capacidade física (prédios, instalações, etc.); corpo docente utilizado e as perdas por deserção e reprovação". Concluíram que enquanto a produtividade cresceu no ensino primário, no ensino médio e superior decaiu, a do primeiro em menor escala (p. 109). Diante disso, destacou-se a necessidade de superar a capacidade ociosa do sistema, no que se referia à capacidade física e o corpo docente que nele atuava. Justificavam sua estratégia discursiva em relação ao último fator mencionado, afirmando: "uma baixa relação alunos/professor, num país desenvolvido, significa geralmente que as condições qualitativas do ensino são excelentes", enquanto que "nos países subdesenvolvidos, ao contrário, essas relações, quando demasiado baixas, 
refletem sérios desperdícios encontrados no sistema, por empreguismo, absenteísmo exagerado, etc." (p. 113). E ainda:

A ação conjunta da deserção e da reprovação ocasionam um baixíssimo rendimento no ensino brasileiro. Adicionando-se a este fato a capacidade ociosa que se verifica em certos níveis e ramos educacionais, pode-se ter uma ideia nítida do nível de produtividade do sistema no País (idem, ibidem, p. 116).

A esse respeito, a Mensagem apresentada ao Congresso Nacional pelo Presidente da República, Humberto de Alencar Castelo Branco, em 1965, reafirma o diagnóstico apresentado pelos autores do Plano Decenal de que:

É do conhecimento de todos a grave e lamentável situação que a Revolução encontrou no setor da educação, onde o poder público não pecou apenas pela omissão, mas também pela complacência e, por vezes, pela ação deletéria. A existência de mais de 30 milhões de brasileiros analfabetos e a ocorrência de extensos hiatos em nossa estrutura de mão-de-obra são efeitos naturais da persistência prolongada de elevados déficits educacionais, agravados pela alarmante deserção e pelo baixo aproveitamento dos estudantes, em geral, além de um elenco numeroso e complexo de problemas secundários, incluindo a falta de especialização pedagógica de grande parte do corpo docente, o divórcio entre a escola e o meio, a vigência de regimes escolares com horários reduzidíssimos, etc. (BRASIL, 1987, p. 380).

Tais diagnósticos serviram de estratégias discursivas e permearam as ações governativas no tocante à prática do planejamento. Bomeny (1993, p. 26-27) assinala que, no Brasil, a perspectiva economicista, recorrente nos diagnósticos e distintos projetos de nação, levaram ao fortalecimento do Estado em detrimento da nação. Para protagonizar as pretensas intervenções na educação e, também, na saúde pública, era imperativa a defesa da ação estatal. No plano discursivo, a defesa de um sistema centralizado sob controle do Estado apresenta-se como uma forma de reagir à estrutura descentralizada, considerada um efeito perverso da Constituição Liberal de 1891, que deixou "[...] aos vícios privados o que tinha que ser tratado como virtudes públicas". Ao longo das décadas de 1960 e 70, essas concepções foram expressas pelos formuladores do pensamento autoritário no Brasil, que, preocupados em formular projetos nacionais, consagram o Estado como instância responsável pela instalação de uma nova ordem.

As questões raciais, nesse período, não ficaram isentas de diagnósticos e previsões de uma equipe de especialistas. Por exemplo, durante o Regime Militar no Brasil, também houve diagnósticos e previsões de que poderia haver conflitos raciais manifestados pública e abertamente no Brasil do futuro, ou seja, do ano 2000. Nessa época, o jornalista José Itamar 
de Freitas organizou uma equipe de pesquisadores e intelectuais ${ }^{9}$ para discutir o que seria o Brasil no ano 2000. O resultado desse trabalho "prospectivo do problema racial brasileiro" (FREITAS, 1969, p. 91), foi publicado em 1969, por meio da Editora Biblioteca do Exército Brasileiro dirigida pelo Cel. Fernando Soter da Silveira, intitulado: Brasil ano 2000: o futuro sem fantasia.

Seguindo as postulações feitas pelo sociólogo Nelson Mello e Souza, da Fundação Getúlio Vargas, o organizador da publicação assegurava que "não chegamos a ser racistas segregadores", mas que também não podemos "nos orgulhar de nossa democracia racial"'. E, indaga:

\begin{abstract}
Como reagiremos - por exemplo - quando os negros vencerem as dificuldades sociais e econômicas que os segregam, deixarem de ser apenas 448 universitários em 5.600.000 indivíduos? Hoje, os negros não incomodam, mas o que acontecerá quando eles tiverem - ainda que uma minoria expressiva deles - poder econômico para comprar títulos de clubes fechados, ou forçar sua entrada nos colégios mais caros, ou forçar sua admissão nos escritórios ou postos importantes, ou morar nas zonas residenciais de "primeira classe"? Estaremos maduros, bastante, para aceitálos como irmãos em tudo, ou vamos partir para conflitos raciais? (FREITAS, 1969, p. 07 - grifos do autor).
\end{abstract}

Por meio da noção conceitual de Bourdieu (2000) acerca das estratégias discursivas e utilizada pelo organizador da obra acima citada, percebemos que o mesmo assume um sistema de conceitos e proposições futurísticas que visam explicar o mundo social e que se encontra instituídas na exterioridade das consciências particulares. Assim, o autor de forma posicionada "confere ao discurso propriedades distintivas" (BOURDIEU, 2008, p.25) e admitia que seria por iniciativa do grupo social branco que provavelmente haveria ataques ou conflitos raciais no Brasil do futuro. Mais adiante, lança outro questionamento "como reagirão os brancos à ascensão social do negro?” e, mais uma vez, Freitas (1969, p. 93) concorda com a análise do sociólogo e conclui que poderia haver lutas raciais no Brasil do ano de 2000, embora o país "não deverá ter o colorido selvagem do racismo nos Estados Unidos e na África do Sul".

Embora, os governos militares brasileiros (1964-1985) negassem oficial e publicamente a discriminação contra os negros, e, consequentemente, afirmassem a existência de uma "democracia racial" no Brasil, é instigante imaginar como a Ditadura Militar permitiu a publicação de um livro sob o patrocínio da Biblioteca do Exército Brasileiro. Livro este que

\footnotetext{
${ }^{9}$ De acordo com Freitas (1969, p. 11), a equipe de pesquisa era composta por: a) Economia: Gilberto Paim; Aloysio Biondi; b) Educação: Arnaldo Niskier e seguintes colaboradores Theodolindo Cerdeira (MEC) e Paulo Roberto Monteiro de Barros; c) Sociologia: Nelson Mello e Souza (FGV); d) Saúde Pública: Narciso Mello Teixeira e Eduardo de Mello Kertézs (IPEA); e) Urbanismo: Maurício Nogueira Batista; f) Etnologia: Carlos Castilho e colaboradores: Otávio Alves Velho e Giralda Pitanguay (Museu Nacional); g) Religião $e$ Telecomunicações: Rose Marie Muraro (FGV); h) Colaborador Especial: Glória Nogueira e, Fotografias de Kaoru Higuchi.

\begin{tabular}{|l|l|l|l|l|l|} 
(C) Rev. Inter. Educ. Sup. & Campinas, SP & v.3 & n.3 & p.678-705 & set./dez. 2017 \\
\hline
\end{tabular}
}


afirmava que "a chamada 'democracia racial' sempre foi um mito" (FREITAS, 1969, p. 91) e que "o negro e o mulato poderão recorrer à violência, nos próximos 30 anos, para se integrarem na sociedade industrial de massas que vai marcar o Brasil" (p. 87). Talvez seja por considerar o grupo social negro como mais um "inimigo interno" da Nação. Pois, "a realidade do negro no Brasil sempre instigou a intelectualidade em áreas como a antropologia e a sociologia" (GOMES, 2004, p. 9).

Sem dúvida, a ideologia da "democracia racial" havia se firmado e era amplamente compreendida. Dentro do referido contexto, Telles (2012, p. 33) também menciona que os governos militares "estavam bem cientes do racismo e da desigualdade racial [...] suas ações a favor da democracia racial provavelmente não foram tão cínicas, se não apenas uma estratégia muito bem planejada para prevenir a polarização racial". Nas décadas de 1970 e 1980, a "democracia racial" continuou sendo amplamente aceita pela maioria dos setores da sociedade brasileira, a despeito das contestações acadêmicas e dos protestos negros reiniciados em meados da década de 1970.

Nesta fase de governo militar, há um elevado grau de analfabetismo e um baixo percentual de escolarização entre a população ativa do país. A política educacional brasileira, nesse período, esteve articulada ao ajuste ideológico que o golpe necessitava: combater o movimento "nacional desenvolvimentista" para garantir o "desenvolvimento com segurança". Médici afirmava que grande parte da população era constituída por analfabetos, e mais, este era um dos "mais graves e prementes problemas que o Governo deveria enfrentar e solucionar” (BRASIL, 1987, p. 405).

Esses eram os dois projetos para o Brasil. De um lado o projeto de Vargas, chamado de nacional-desenvolvimentismo, e de outro um projeto que via na aliança com o capital estrangeiro à solução para os problemas do país como a escassez de capital, de tecnologia e de poupança externa. Este último denominado de "desenvolvimento dependente associado". Para Fonseca e Monteiro (2008, p.37) a palavra "nacional" auxilia na diferenciação de estilo de desenvolvimento e que aparece de forma mais nítida após 1964. Só a partir daí "segurança e desenvolvimento" fará sentido como lema do Regime Militar, com a ideia de que um realimenta o outro e ambos justificam a necessidade do "regime de exceção".

A meta básica desse período constituiu, efetivamente, a expansão dos sistemas de ensino, de modo a garantir o acesso à escola para a maioria da população, bem como o aumento e especialização do pessoal docente. Fato destacado, pelo então Governador do Estado do Pará, Fernando José de Leão Guilhon, “a expansão da rede e o aumento e especialização do pessoal docente e técnico administrativo exigiu da SEDUC um investimento maciço de recursos financeiros [...] próprios e de convênios diversos assinados com órgãos federais" (PARÁ, 
1970, p. 87)". Entretanto, se a situação educacional, passou a não ser tão grave, do ponto de vista quantitativo, fica patente sua má qualidade; a repetência contínua, em especial nas séries iniciais. A propósito, fato esse apresentado no período base da análise dos dados educacionais, dispostos no Plano Estadual de Educação do Pará que considerou o período de 1980-1985, a média de alunos fora das faixas etárias chegou acerca de $38 \%$ no Pré-Escolar, $21 \%$ no $1^{\circ}$ Grau e $46 \%$ no $2^{\circ}$ Grau (PARÁ, 1987, p. 14).

Neste aspecto, Cunha (1985, p. 56-60) observou que no ensino primário, em 1970, havia 6,5 milhões de crianças de 07 a 14 anos fora da escola, "em 1980, elas já eram 7,5 milhões. Ou seja, os excluídos da escola aumentaram de um milhão de 1970 a 1980" (grifos do autor). Mais adiante, enfatiza que "a proporção de analfabetos de 14 de idade continuou em 9,8\% na zona urbana e na zona rural houve uma discreta redução, de $41,9 \%$ para $36,8 \%$ naquele decênio". O analfabetismo continuou a ser um problema na sociedade brasileira e um aspecto que será abordado em todos Planos educacionais. Ainda segundo o autor, em 1970, a taxa de analfabetismo era de 33, 6\% para a população acima de 15 anos e, em 1980, essa taxa reduz para $25,4 \%$. Portanto, o número de analfabetos aumentou de "540 mil pessoas, que foram se somar aos 18,2 milhões de iletrados que havia em 1970".

Essa é uma formulação fundamental, porque nos conduz à consideração de que a ditadura tratava o analfabetismo como um mal em si mesmo, omitindo as reais determinações sociais que constituíam as causas dos problemas educacionais. A legislação de 1961 não regulamentou as formas de institucionalização dos cursos que trataram, especificamente, dessa questão - o supletivo - reservando ao Estado somente o direito de aplicar os exames finais e expedir os diplomas, conforme aponta o Art. $99^{10}$. Portanto, essa foi mais uma questão para que as empresas privadas explorassem as aspirações educacionais das classes trabalhadoras.

Nessa perspectiva, na Mensagem encaminhada, em 1965, ao Congresso Nacional, o Presidente Castelo Branco afirma esse propósito ao dizer que: "O governo propôs e obteve a aprovação do Congresso para a instituição do salário-educação, cujo espírito é o da participação de toda a comunidade na solução de um de seus problemas fundamentais - o analfabetismo [...] respeitando a valiosa contribuição da iniciativa privada" (BRASIL, 1987, p. 381).

Evidenciou-se, neste período, que as concepções acerca da criação e preservação de condições políticas e sociais para que a economia se expandisse definiram as novas funções

\footnotetext{
${ }^{10}$ Art. 99 - "Aos maiores de dezesseis anos será permitida a obtenção de certificados de conclusão do curso ginasial, mediante a prestação de exames de madureza, após estudos realizados sem observância do regime escolar. Parágrafo único: Nas mesmas condições, permitir-se-á a obtenção do certificado de conclusão do curso colegial aos maiores de dezenove anos".

\begin{tabular}{|l|c|c|c|c|c|} 
(C) Rev. Inter. Educ. Sup. & Campinas, SP & v.3 & n.3 & p.678-705 & set./dez. 2017 \\
\hline
\end{tabular}
}


do Estado, as quais se configuravam em: a) reforço do Executivo e consequente remanejamento das forças sociais na estrutura do poder. A população foi alijada da participação nas decisões políticas e econômicas; b) aumento do controle exercido pelo Conselho de Segurança Nacional; c) centralização e modernização da administração pública; d) cessação do protesto social (ROMANELLI, 1994, p. 194).

Assim, a política educacional desse período caracterizou-se pelos Planos Nacionais de Desenvolvimento e seu desempenho por meio dos Planos Setoriais de Educação e Cultura, os quais se constituíram nas matrizes para os textos oficiais ou não sobre educação. Salientamos que o II Plano Setorial de Educação e Cultura (II PSEC - 1975/1979) define a educação como "agente e objeto das reformas sociais", sendo esta uma "função do sistema social" (BRASIL, 1974, p. 31). Essa afirmação encontra seu fundamento nos pronunciamentos oficiais, nos planos e leis educacionais e na própria atuação do governo militar.

Não obstante, a educação foi, paulatinamente, assumindo posição relevante na ideologia do desenvolvimentismo. O governo do general Médici afirma oficialmente, em Mensagem enviada ao Congresso Nacional, o papel revolucionário que ela exerceria no progresso do país, "pondo-a a serviço da preparação dos estudantes para serem úteis, desde cedo, à comunidade" (BRASIL, 1987, p. 83). Para isso, uma série de programas e projetos educacionais considerados prioritários foi estabelecida por meio dos Planos globais. Tentativa de construção de um processo de "brasilidade", culminando num intento, ainda que influenciado pelo ideário militar, de acentuado nacionalismo, não apenas no âmbito oficial, como também em ambientes civis, ou pelo menos, aparentemente fora do âmbito militar.

Nesse sentido, nas escolas, a disciplina Educação Moral e Cívica, obrigatória em todos os âmbitos de ensino, garantiria a aquisição do nacionalismo por meio de hábitos desejados, bem como contribuiria para o fortalecimento do culto à Pátria apoiando-se em instituições, como a família e a religião ${ }^{11}$, conforme aponta o Art. $3^{\circ}$ do Decreto $n^{\circ} 68.065^{12}$, de 14 de janeiro de 1971, assinado pelo Presidente Médici ${ }^{13}$. Desse modo, foi possível propagar o "milagre econômico brasileiro", "apontando um conjunto de bons resultados no campo econômico" (VIEIRA, 1985, p. 37), obtido pelas altas taxas de crescimento aliadas aos baixos índices de

\footnotetext{
${ }^{11}$ Este aspecto pode ser também, observado no Parecer no 94/71 instituído pela Comissão Nacional de Moral e Civismo que teve como relator o arcebispo-conselheiro Luciano José Cabral Duarte. O Parecer proclamava que a religião é que era a base da moral a ser ensinada. Entretanto, afastavam todas as religiões afro-brasileiras, e mais, "o mesmo acontecia com as crenças indígenas".

12 O Decreto $n^{\circ} 68.065$, de 14 de janeiro de 1971, regulamenta o Decreto- Lei $\mathrm{n}^{\circ}$ 869, de 12 de setembro de 1969, que dispõe sobre a inclusão da EMC como disciplina obrigatória, nas escolas de todos os graus e modalidades dos sistemas de ensino no País, e dá outras providências.

${ }^{13}$ Ver ainda, Circe Bittencourt (1990) em Pátria, Civilização e Trabalho: o ensino de história nas escolas paulistas. São Paulo: Edições Loyola, p. 176-177.

\begin{tabular}{l|c|c|c|c|c} 
(C) Rev. Inter. Educ. Sup. & Campinas, SP & v.3 & n.3 & p.678-705 & set./dez. 2017 \\
\hline
\end{tabular}
}


inflação e endossadas pela intensificação da entrada de capital estrangeiro, a qual pode ser percebida nas Mensagens Presidenciais ${ }^{14}$ e nos Planos Nacionais de Desenvolvimento.

É importante ressaltar que o desenvolvimentismo autoritário dos militares guardava as devidas proporções do nacionalismo de esquerda do período anterior a 1964. Os intentos nacionalistas que influenciaram os governos militares a partir de 1967 não impediram o dinamismo das empresas estrangeiras. Eles apenas, segundo Motta (2014, p. 84), "buscaram corrigir o que consideravam a excessiva influência externa favorecida por Castello Branco, além de preservar o controle nacional sobre certas áreas estratégicas".

Em relação ao plano, denominado de Plano Setorial de Educação e Cultura - PSEC, instaurado nos anos áureos do Regime Militar, para o período de 1972 - 1974, sob a gestão do Ministro da Educação e Cultura Cel. Jarbas Gonçalves Passarinho, contém três partes. São elas: a primeira, o setor educacional do desenvolvimento; a segunda trata dos instrumentos da execução da estratégia educacional e, por fim, o elenco de projetos. Esse Plano destaca a educação como fator de desenvolvimento, não se dissociando da concepção anterior de operacionalização do sistema produtivo, devendo esta se assentar "na formação de uma adequada estrutura de recursos humanos, condizentes com as necessidades socioeconômicas, políticas e culturais brasileiras, e no incremento da rentabilidade, produtividade e eficiência do sistema educacional" (BRASIL, 1972, p. 19). Dada a configuração política e educacional com que se apresentava a realidade brasileira, evidencia-se, mais uma vez, a concepção economicista da educação, pois o agente é tanto fator de produção, quanto gerador de retorno às novas demandas, visto que ele também será destinatário do "investimento em favor do desenvolvimento econômico e social" (p. 18). Em suma:

\begin{abstract}
Isto será feito, sobretudo pela melhoria da qualidade do ensino, da eliminação da capacidade ociosa, da planificação do crescimento quantitativo da oferta de vagas, da adaptação dos currículos à realidade nacional e às peculiaridades regionais, e da articulação da educação, da pesquisa e da tecnologia com o desenvolvimento global do País. (BRASIL, 1972, p. 19).
\end{abstract}

A educação, no I PSEC, era compreendida como "um dos fatores condicionantes do desenvolvimento", na construção de uma "sociedade democrática". Para atenuar tal necessidade, propunha a oferta aos agentes sociais de "iguais oportunidades de se educarem". De tal modo, "a educação democrática implica também na educação para o desenvolvimento" (BRASIL, 1969, p. 18-19).

Os seus objetivos eram "estender matrícula do $1^{\circ}$ grau a $80 \%$ das crianças dos 7 aos 14 anos de idade; eliminar o analfabetismo de adolescentes e adultos na faixa dos 15 aos 35 nos de

\footnotetext{
${ }^{14}$ Nas Mensagens presidenciais enviadas ao Congresso Nacional em 1970, 1972, 1973 e 1974, Médici assevera os incentivos econômicos recebidos do BID, dos acordos MEC/USAID e outros de natureza privada.

\begin{tabular}{l|c|c|c|c|c} 
(C) Rev. Inter. Educ. Sup. & Campinas, SP & v.3 & n.3 & p.678-705 & set./dez. 2017
\end{tabular}
}


idade; preparar o homem para o exercício da cidadania; expandir os sistemas de treinamento; proporcionar terminalidade ao ensino de $2^{\circ}$ grau, visando à formação de técnicos de nível médio; expandir a oferta do ensino superior, especialmente nas áreas das técnicas, da formação do magistério e das ciências da saúde; acelerar a Reforma Universitária; instituir os centros regionais de pós-graduação; manter a gratuidade para todos que sejam carentes ou tenham insuficiência de recursos" (BRASIL, 1969, p. 19-20).

Conforme a compreensão estabelecida por Freitag (1986, p. 102), o I PSEC pretendia promover a síntese entre antagonismos que marcaram a história da educação, em particular, do Brasil, por meio da fusão de elementos antes adversos, quais sejam: educação nacional e economia. Essa atitude era inerente a uma política nacional que se intitulava harmônica, em todos os sentidos:

\begin{abstract}
De 33 projetos elaborados para a realização do plano, 4 visam alcançar os objetivos definidos para a escolarização de primeiro grau; três são dedicados à reforma do ensino médio (implantação da profissionalização e terminalidade, melhoria da remuneração do magistério) e oito se preocupam diretamente com a implantação da reforma universitária. Independente do ensino formal, três projetos são formulados para garantir a melhoria da formação de mão-de-obra, estando aqui incluídos os projetos de alfabetização e educação de adultos. Os demais se preocupam com reformas administrativas, pesquisas educacionais, programas de assistência técnica, aos Estados e Territórios (FREITAG, 1986, p. 102).
\end{abstract}

Deste modo, o documento que traduz o I PSEC dizia pretender situar o Brasil, "no espaço de uma geração, na categoria das nações desenvolvidas" (BRASIL, 1974, p. 15). Para tanto, insistia-se na perspectiva de "estabilidade sociopolítica", entendida, principalmente, como "ausência de dissensão" para manter "a confiança dos investidores, especialmente os estrangeiros" (ALVES, 1984, p. 147). Ademais, o documento finaliza enfatizando que "a política educacional vem sendo fielmente cumprida com o objetivo de proporcionar segurança, contribuir direta e eficazmente para o desenvolvimento brasileiro" (idem, p. 39).

Nesse sentido, consolida-se a eficácia da educação como instrumento de distribuição de renda e equalização social por meio da Teoria do Capital Humano. Essa teoria, segundo Frigotto (2010), apareceu assim como instrumento indispensável aos países subdesenvolvidos para alcançar o desenvolvimento pretendido. E, assim, Frigotto (2010, p. 55-56) lembrava que essa visão instrumentalista e economicista da educação era bastante influenciada pela teoria do capital humano, teoria vigente na época e amplamente defendida pelos generais-presidentes, pelos ministros da Educação e pelos técnicos do MEC.

Essas estratégias discursivas se fazem presentes na elaboração dos Planos Setoriais de Educação. O recurso à educação como "preparo da mão de obra" está fundamentado na mesma assertiva de que investindo em educação o agente social amplia as possibilidades de

n.3 $\quad$ p.678-705
set./dez. 2017 
inserção no mercado de trabalho e de integração com o sistema produtivo. Assim, a escolarização destes agentes é vista como um instrumento para reduzir as disparidades na distribuição de renda e, consequentemente, das desigualdades sociais.

Quanto ao II PSEC, estabelecido para o período de 1975 - 1979, foi aprovado na gestão de Ministro da Educação e Cultura Ney Amintas de Barros Braga, do Governo Militar do General Ernesto Geisel, com poucas ressalvas que não o alteram em seus princípios básicos, haja vista que retoma o anterior ao dizer: "Na fase presente de nossa evolução social, a educação brasileira há de concorrer para o objetivo comum que é o projeto de desenvolvimento nacional e, possibilitado por este, o projeto humano pessoal de cada indivíduo" (BRASIL, 1979, p. 08). Constata-se no referido Plano, pela primeira vez, o destaque à cultura brasileira ressaltando "alguns traços característicos de uma cultura básica compartilhada por todos” (p. 26). Essa compreensão projetava-se na medida em que "podemos legitimamente extrair a convicção de que a construção de um país e a grandeza de seu povo não se fundamentam somente em alicerces materiais" (idem, ibidem).

A interlocução maior nesse ponto parece ser mais do agente social do desenvolvimento preocupado com o "capital humano" do que o militar, e o documento é todo redigido numa perspectiva "humanista", que permite observar "a plena realização do homem brasileiro como pessoa", e enfatizar que a "cultura é a plenitude da vida humana no seu meio". As estratégias básicas já não invocam apenas o desenvolvimento econômico e a segurança nacional, mas, sobretudo o social, e que dentro desse desenvolvimento social há um lugar de destaque para a cultura (MICELI, 1984, p. 92).

O plano quinquenal (II PSEC) foi um documento de política nacional que abrangeu as áreas da educação, cultura e desporto do ensino básico ao superior. De acordo com Fávero et al. (1992, p. 07), “constitui uma síntese bastante bem elaborada da teoria do capital humano e do planejamento da educação, sob a ótica da análise de sistemas que praticamente fecha um ciclo". Vale ressaltar que o referido plano foi elaborado sob o impacto das crises do petróleo e monetária internacional, com tensões econômicas em âmbito mundial e, por isso, foi voltado para o homem brasileiro nas suas diferentes dimensões e aspirações, as quais deverão "simultaneamente, oferecer ao sistema produtivo a mão de obra por essa via qualificada" (II PSEC, 1976, p.34). A esse respeito, Vieira (1985, p. 50) contribui: "isto quer dizer que as necessidades da população brasileira se colocavam em segundo lugar, ficando em primeiro lugar os interesses do mercado externo, dominado por estrangeiros". 
Com o processo de "abertura", uma mudança no planejamento será observada. No tocante ao III Plano Setorial de Educação, Cultura e Desporto - PSECD ${ }^{15}$, proposto para o período de 1980-1985, seus objetivos buscavam incorporar os problemas sociais do início da década de 1980, ao mesmo tempo, propalavam o atendimento à população excluída socialmente com o aumento da renda pessoal e uma suposta distribuição dos benefícios do desenvolvimento, e faziam isso por meio de "uma política social envolvendo um esforço integrado das áreas sociais e econômicas para a superação das desigualdades sociais" (BRASIL, 1979b, p. 09) na resolução da pobreza no Brasil. Vale ressaltar que o documento conclama a ação integrada entre a educação, cultura e desporto, pois se configuram no "elo necessário entre as políticas que vêm sendo desenvolvidas e as novas propostas, acentuando o caráter tridimensional do setor educação, cultura e desporto, sem insinuar qualquer justaposição estanque" (idem, p. $15)$.

Em face do contexto de promover a "justiça social", a educação, portanto, "é direito fundamental e basicamente mobilizadora, encontrando, especialmente, na sua dimensão cultural, o espaço adequado para a conquista da liberdade, da criatividade e da cidadania" (BRASIL, 1980, p. 14 - grifos nossos).

Nesse sentido, é claramente explícita a assimilação do vocabulário crítico da sociedade civil (GERMANO, 2005, p. 228), progredindo, inclusive, no reconhecimento da inexistência de uma sociedade democrática e admitindo a educação como um espaço para a conquista da cidadania. São ações que parecem negar o autoritarismo vigente, bem como os procedimentos de planejamento adotados anteriormente, mas que se encontra presente na doutrina da ESG e, por conseguinte no desenvolvimentismo dos militares, nesse período.

Dessa forma, diante da crise social intensificada no início dos anos de 1980, advinda do modelo de dependência externa e da situação internacional com a segunda crise do petróleo, a ênfase na questão social foi ganhando corpo nas propostas públicas elaboradas (DUPAS, 1987), bem como nas mensagens presidenciais, inclusive como constituinte das prescrições de organismos internacionais de financiamento que, por meio da concessão de empréstimos passaram a financiar como prioridade a "contenção da pobreza” (SINGER, 1986, p. 42).

15 O III PSECD foi concebido e implantado na Gestão do Governo Militar do General João Batista de Figueiredo, que teve como Ministros da Educação e Cultura Eduardo Mattos Portella de março de 1979 a novembro de 1980, General Rubens Carlos Ludwig, no período de novembro de 1980 a agosto de 1982 e Esther de Figueiredo Ferraz de agosto de 1982 a março de 1985. Portella assumiu em meio a um amplo debate sobre a situação educacional no Brasil, no contexto do processo de "abertura política" iniciado no Governo Geisel. Por não ser do círculo político militar, Portella encontrou resistências e foi substituído pelo General Rubens Ludwig, integrante do círculo militar, do Conselho Nacional de Segurança que retoma os preceitos da tecnoburocracia, associado à produtividade e educação. E por fim, no ano de 1982 assumiu o Ministério da Educação e Cultura, Esther Ferraz, seu principal feito foi a aprovação da Lei 7.044 de 1982.

\begin{tabular}{l|l|l|l|l|l} 
(C) Rev. Inter. Educ. Sup. & Campinas, SP & v.3 & n.3 & p.678-705 & set./dez. 2017
\end{tabular}


Articulado à proposição de "abertura política" propagada naquele período, o III PSECD teve sua elaboração subsidiada por discussões regionalizadas ${ }^{16}$. Essa ação encontra-se explicitada no documento "Subsídios para a elaboração, do III Plano Setorial de Educação, Cultura e Desportos", o qual representou a possível síntese desses encontros regionalizados, quando foram expostos os desafios a superar: a redução das desigualdades sociais; o crescimento demográfico; a universalização da educação básica; a eficiência do sistema escolar; o desenvolvimento cultural; a flexibilidade regional e programática (BRASIL, 1979c, p. 8-10).

Nesse documento, pode-se visualizar a concepção fundamental, as linhas prioritárias de ação que orientariam o trabalho do setor educacional durante os cinco anos seguintes, configurando-se nas diretrizes da política educacional brasileira daquele período (1980-1985). Em contrapartida, nesse documento percebemos poucas modificações em relação ao documento final aprovado. Enquanto no texto que trata dos "Subsídios para a elaboração do III Plano Setorial de Educação, Cultura e Desportos" a linha de ação denominada de "sistema de captação e alocação de recursos" é considerada prioritária, no documento final essa linha é apresentada como um dos objetivos gerais. Outro exemplo de alteração se refere à "modernização técnico-administrativa", a qual também é retirada das linhas de ação e incluída como um dos objetivos gerais. Entretanto, essas alterações apresentadas no texto final do III PSECD não omitem os pressupostos diretivos e propositivos que direcionavam a política educacional do período em questão.

Outro aspecto percebido no documento "Subsídios para a elaboração do III Plano Setorial de Educação, Cultura e Desportos" e que, posteriormente, apareceria no texto final do III PSECD, diz respeito à política educacional que deveria estar "voltada para um dos pontos centrais da política social, a saber, aquela que está se chamando, de alguma maneira, de compromisso com a pobreza" (BRASIL, 1979c, p. 67).

Desse modo, concordamos com Freitag (1986, p. 106-107), quando exorta que a política educacional brasileira "se apropriou sem questionamentos desses modelos da economia da educação" e passará com auxílio do planejamento "a transformar o sistema educacional de tal maneira que ele cumpra todas as funções de reprodução necessárias à manutenção das relações de produção [...] de reprodução da força de trabalho" (grifo da autora). Nessa perspectiva, o III PSECD continha uma política educacional fragmentada, cujo pretexto era atender as especificidades de cada região do país de modo a eliminar os "focos de pobreza", especialmente no campo e nas periferias urbanas.

Sabe-se, contudo, que a política de desenvolvimento não mais poderia atuar como nas décadas de 1960 e 70, pois não seria funcional à nova realidade que se impôs a partir dos anos

${ }^{16}$ Ver Subsídios para elaboração do III PSECD, 1979.

\begin{tabular}{l|l|l|}
\hline (C) Rev. Inter. Educ. Sup. & Campinas, SP & v.3
\end{tabular}

n. 3

p.678-705

set./dez. 2017 
1980. Nesse período, já não existia o clima de "euforia desenvolvimentista" que marcou os planos anteriores. No Quadro 1 apresentamos a síntese que comporta as estratégias discursivas mobilizadoras dispostas nos planos educacionais.

Quadro 1. Síntese das estratégias discursivas dos planos nacionais no período do Regime Militar

\begin{tabular}{|c|c|c|}
\hline $\begin{array}{c}\text { PLANOS } \\
\text { NACIONAIS / } \\
\text { GOVERNOS }\end{array}$ & ESTRATÉGIAS DISCURSIVAS & $\begin{array}{c}\text { CATEGORIAS DISCURSIVAS DE POLÍTICA } \\
\text { EDUCACIONAL }\end{array}$ \\
\hline $\begin{array}{l}\text { Plano Trienal de } \\
\text { Desenvolvimento de } \\
\text { Econômico e Social }\end{array}$ & $\begin{array}{l}\text { Modelo de "substituição de importações", para } \\
\text { superar desequilíbrios estruturais da economia } \\
\text { brasileira; reforma fiscal; mobilização de } \\
\text { recursos } \quad \text { externos; desenvolvimento } \\
\text { modernizador; controle cada vez maior do Estado } \\
\text { sobre a vida da Nação; }\end{array}$ & $\begin{array}{l}\text { a) atender aos objetivos nacionais; } \\
\text { b) expansão na taxa de escolaridade; } \\
\text { c) ênfase no planejamento para o } \\
\text { desenvolvimento social; } \\
\text { d) metas e diagnósticos externos; } \\
\text { e) acelerar o desenvolvimento econômico }\end{array}$ \\
\hline $\begin{array}{lr}\text { Plano de } & \text { Ação } \\
\text { Econômica } & \text { de } \\
\text { Governo } & \\
\text { Governo } \quad \text { Castelo } \\
\text { Branco (1964 } & \text {-1967) }\end{array}$ & $\begin{array}{l}\text { Ampla reforma da política econômica e de seus } \\
\text { instrumentos básicos, inclusive no plano } \\
\text { institucional; reorganização do Estado; início de } \\
\text { forte expansão do setor estatal, com criação de } \\
\text { empresas públicas; forte intervencionismo e } \\
\text { centralização econômica; Resumia-se no controle } \\
\text { da inflação; retomada do desenvolvimento } \\
\text { econômico. }\end{array}$ & $\begin{array}{l}\text { a) atender a funcionalidade econômica; } \\
\text { b) aperfeiçoamento dos recursos humanos; } \\
\text { c) expansão de matrículas; } \\
\text { d) elevado índice de analfabetismo; } \\
\text { e) seguia às determinações do nacional- } \\
\text { desenvolvimentismo; }\end{array}$ \\
\hline $\begin{array}{l}\text { Plano Decenal de } \\
\text { Desenvolvimento } \\
(1966-1976) \\
\text { Governo Castelo } \\
\text { Branco }(1966-1967)\end{array}$ & $\begin{array}{l}\text { Plano de caráter abrangente; o Diagnóstico } \\
\text { serviria como o fundamento das metas e } \\
\text { objetivos a serem programados para cada setor } \\
\text { dentro do planejamento global; atender às } \\
\text { necessidades de mão de obra especializada; } \\
\text { projeto nacional de desenvolvimento; } \\
\text { participação dos recursos financeiros externos. }\end{array}$ & $\begin{array}{l}\text { a) educação foi considerada como "indústria } \\
\text { de prestação de serviços"; } \\
\text { b) objetivo principal de salientar a } \\
\text { importância do fator educação no processo } \\
\text { de desenvolvimento econômico e social.; } \\
\text { c) princípios de eficiência, flexibilidade, } \\
\text { modernização, racionalidade e } \\
\text { subordinação ao modelo econômico; }\end{array}$ \\
\hline $\begin{array}{l}\text { I Plano Setorial de } \\
\text { Educação e Cultura }\end{array}$ & $\begin{array}{l}\text { Plano setorial elaborado considerando os } \\
\text { "princípios doutrinários" da Constituição Federal, } \\
\text { da DSN e do I PND; Grandes projetos de } \\
\text { integração nacional; planos especiais de } \\
\text { desenvolvimento regional; Projeto nacional- } \\
\text { desenvolvimentista, "milagre econômico } \\
\text { brasileiro"; bons resultados no campo } \\
\text { econômico; dois planos básicos de } \\
\text { desenvolvimento científico e tecnológico e um } \\
\text { primeiro plano nacional de pós-graduação. }\end{array}$ & $\begin{array}{l}\text { a) a educação como fator de desenvolvimento } \\
\text { e de segurança nacional; } \\
\text { b) visão economicista da educação; } \\
\text { c) operacionalizar o sistema produtivo; } \\
\text { d) elevados índices de deserção e reprovação; } \\
\text { e) formação de técnicos de nível médio; } \\
\text { f) acelerar a reforma universitária; } \\
\text { g) articulação da educação, da pesquisa e da } \\
\text { tecnologia com o desenvolvimento global } \\
\text { do País. }\end{array}$ \\
\hline $\begin{array}{l}\text { II Plano Setorial de } \\
\text { Educação e Cultura }\end{array}$ & $\begin{array}{l}\text { Crescente preocupação com o campo social; } \\
\text { ampliação dos aspectos culturais e uma política } \\
\text { especial para a área de educação física; abrangeu } \\
\text { as áreas da educação, cultura e desporto. }\end{array}$ & $\begin{array}{l}\text { a) "redistributivismo" e o "participacionismo; } \\
\text { b) preservação e enriquecimento dos valores } \\
\text { humanos e culturais básicos; } \\
\text { c) incrementar os programas de educação } \\
\text { física e desportos e de assistência ao } \\
\text { estudante; } \\
\text { d) ampliar o atendimento à Ed. pré-escolar e }\end{array}$ \\
\hline
\end{tabular}

\begin{tabular}{|l|c|c|c|c|c|} 
(C) Rev. Inter. Educ. Sup. & Campinas, SP & v.3 & n.3 & p.678-705 & set./dez. 2017 \\
\hline
\end{tabular}




\begin{tabular}{|c|c|c|c|}
\hline & & & \\
\hline $\begin{array}{l}\text { III Plano Setorial de } \\
\text { Educação, Cultura e } \\
\text { Desportos }\end{array}$ & $\begin{array}{l}\text { Buscava incorporar os problemas sociais do } \\
\text { início da década de 1980; propalava o } \\
\text { atendimento à população excluída socialmente } \\
\text { com o aumento da renda pessoal e uma suposta } \\
\text { distribuição dos benefícios do desenvolvimento; } \\
\text { ação integrada entre a educação, cultura e } \\
\text { desporto; discussões regionalizadas. }\end{array}$ & $\begin{array}{l}\text { d) } \\
\text { e) }\end{array}$ & $\begin{array}{l}\text { Processo de "abertura política"; } \\
\text { planejamento descentralizado } \\
\text { participativo; } \\
\text { educação como espaço para a conquista da } \\
\text { cidadania; } \\
\text { caráter redistribuitivo e mobilizador; } \\
\text { dimensões culturais ligadas à identificação } \\
\text { nacional; }\end{array}$ \\
\hline
\end{tabular}

Fonte: Pesquisa Documental realizada pela autora em 2014.

Em síntese, os Planos nacionais aqui apresentados são exemplos de uma política educacional que se fez presente na sociedade brasileira e que caracterizaram a educação como "um dos fatores de transformação social, além de ser um instrumento básico para a plena realização do ser humano" concernentes ao trinômio educação-nacionalismo-identidade nacional. Desse modo, o modelo educacional empreendido teria um "forte conteúdo social" e direcionado por um "nacionalismo positivo" que se afirmava, por meio de dois pressupostos interrelacionados: em primeiro lugar, por "meios para a plena afirmação do homem brasileiro, enquanto pessoa" (e não do homem cívico), de modo a "promover a sua integração na sociedade nacional"; em segundo, pretendia "capacitá-lo como recurso para o desenvolvimento do país - o que, em si mesmo, é afinal um instrumento para a consecução das prioridades anteriores" (BRASIL, 1979, p. 31-33). Em vista disso, o nacionalismo é aqui compreendido como a utilização do símbolo "nação" pela doutrina, pela atividade política, bem como um sentimento compartilhado por uma coletividade.

Podemos, então, constatar o quanto a política educacional do ensino básico ao superior tornou-se uma decorrência do planejamento técnico-econômico, tanto nas suas finalidades, quanto em relação aos seus formuladores, de quem expressa a lógica e o raciocínio próprios, com o qual se aliava a segurança nacional.

É importante mencionar que, por meio dessas estratégias discursivas dispostas nos documentos do período de vigência do Regime Militar, é possível demonstrar aspectos do nacionalismo, da identidade nacional no entrecruzamento com o exercício da cidadania. Foram estratégias construídas com veemência pelo Estado brasileiro - nacional desenvolvimentista - como expressão maior da legitimidade do campo militar ao se projetar para o campo político e, consequentemente, para o educacional. 


\section{REFERÊNCIAS}

ALVES, Maria Helena Moreira. Estado e oposição no Brasil (1964-1984). Petrópolis - RJ: Vozes, 1984.

BOURDIEU, Pierre. Razões práticas: sobre a teoria da ação. Campinas: Papirus, 1990.

BOURDIEU, Pierre. O poder simbólico. Trad. Fernando Tomaz. 3. ed. Rio de Janeiro: Bertrand Brasil, 2000.

BOURDIEU, Pierre. Coisas ditas. Trad. Cassia R. Silveira e Denise M. Pegorim. 5.ed. São Paulo: Brasiliense, 2004.

BOURDIEU, Pierre. A economia das trocas linguísticas: o que falar quer dizer. 2. ed. São Paulo: EDUSP, 2008.

BOURDIEU, Pierre. Regras da arte: gênese e estrutura de campo literário. Tradução de Maria Lucia Machado. São Paulo: Companhia das Letras, 2010.

BRASIL. SUDAM - Superintendência do Desenvolvimento da Amazônia. I Plano de Desenvolvimento da Amazônia, 1972-1974, Belém, [s.n.], 1971.

BRASIL. SUDAM - Superintendência do Desenvolvimento da Amazônia. II Plano de Desenvolvimento da Amazônia: programa de ação do Governo para a Amazônia, 19751979, Belém, 1976.

BRASIL. Biblioteca da Presidência da República. Mensagem Presidencial - João Goulart, Brasília, 1964.

BRASIL. Ministério da Educação e Cultura. Plano decenal de desenvolvimento econômico e social - Educação I. Diagnóstico Preliminar. Ministério do Planejamento e Coordenação Econômica. Escritório de Pesquisa Econômica Aplicada. jun. 1966.

BRASIL. Ministério da Educação e Cultura. Plano decenal de desenvolvimento econômico e social. Diagnóstico Preliminar - Desenvolvimento Social. Educação II. Ministério do Planejamento e Coordenação Econômica. Escritório de Pesquisa Econômica Aplicada, Setembro de 1966.

BRASIL. Biblioteca da Presidência da República. Os Caminhos da Mobilidade Social. 1972, p. 23-29.

BRASIL. Ministério da Educação e Cultura. II Plano nacional de desenvolvimento (19751979). Composto e impresso nas oficinas do Serviço Gráfico do IBGE - Avenida Brasil 15671 - GB, 1974.

\begin{tabular}{l|c|c|c|c|c} 
(C) Rev. Inter. Educ. Sup. & Campinas, SP & v.3 & n.3 & p.678-705 & set./dez. 2017 \\
\hline
\end{tabular}


BRASIL. Ministério da Educação e Cultura. II Plano setorial de educação e cultura (19751979). Ministério da Educação e Cultura/Secretaria Geral. Departamento de Documentação e Divulgação. Brasília: DF, 1979.

BRASIL. Ministério da Educação e Cultura. Diretrizes gerais dos encontros regionais sobre planejamento: III Plano Setorial de Educação, Cultura e Desportos. Ministério da Educação e Cultura/Secretaria Geral. Departamento de Documentação e Divulgação. Brasília: DF, $1979 b$.

BRASIL. Ministério da Educação e Cultura. Subsídios para elaboração do III Plano Setorial de Educação, Cultura e Desportos. Ministério da Educação e Cultura/Secretaria Geral. Departamento de Documentação e Divulgação. Brasília: DF, 1979c.

BRASIL. Ministério da Educação e Cultura. III Plano setorial de educação e cultura (19801985). Ministério da Educação e Cultura/Secretaria Geral. Departamento de Documentação e Divulgação. Brasília: DF, 1980.

BRASIL. Ministério da Educação e Cultura. Instituto Nacional de Estudos e Pesquisas Educacionais. A educação nas mensagens presidenciais (1890-1986). Brasília, INEP, 1987. $2 \mathrm{v}$. anexos.

BOMENY, Helena. Novos talentos, vícios antigos: os renovadores e a política educacional. Estudos Históricos. Rio de Janeiro, v. 6, n. 11, 1993.

COELHO, Mauro Cezar. Educação dos índios na Amazônia do século XVIII: uma opção laica. Revista Brasileira de História da Educação, Campinas, São Paulo, n.18, set./dez., 2008, p. 95-118.

CUNHA, Luiz Antonio; GOÉS, Moacir de. O golpe na educação. Rio de Janeiro: Zahar, 1985.

DREIFUSS, René Armand. 1964: a conquista do Estado: ação política, poder e golpe de classe. 2. ed. Trad. Ayeska Branca de Oliveira Farias et al. Petrópolis, RJ: Vozes, 1981.

DUPAS, Gilberto. Crise econômica e transição democrática: 83/86 - a delicada trajetória brasileira. São Paulo: Klaxon, 1987.

EPEA - Escritório de Pesquisa Econômica Aplicada. Ministério do Planejamento e Coordenação Econômica. Plano Decenal de Desenvolvimento Econômico e Social: Diagnóstico Preliminar, Desenvolvimento Social - Educação I, junho, 1966.

EPEA - Escritório de Pesquisa Econômica Aplicada. Ministério do Planejamento e Coordenação Econômica. Plano Decenal de Desenvolvimento Econômico e Social: Diagnóstico Preliminar, Desenvolvimento Social - Educação II, setembro, 1966. 
FÁVERO, Osmar; HORTA, José Silvério B.; FRIGOTTO, Gaudêncio. Políticas

Educacionais no Brasil: desafios e propostas. Caderno de Pesquisa, São Paulo, n. 83, nov. 1992, p.5-14.

FONSECA, Pedro Cezar Dutra; MONTEIRO, Sérgio Marley Modesto. O Estado e suas razões: o II PND. Revista de Economia Política, v. 28, n. 1 (109), p. 28-46, jan./mar. 2008.

FREITAG, Bárbara. Escola, estado e sociedade. São Paulo: Moraes, 1986.

FREITAS, José Itamar de. Brasil ano 2000: o futuro sem fantasia. Rio de Janeiro: Biblioteca do Exército, 1969.

FRIGOTTO, Gaudêncio. A produtividade da escola improdutiva. 9.ed. São Paulo: Cortez, 2010.

GERMANO, José Willington. Estado militar e educação no Brasil (1964-1985). São Paulo: Editora Cortez 4 ed. 2005.

GOMES, Nilma Lino. Levantamento bibliográfico sobre relações raciais e educação: uma contribuição aos pesquisadores e às pesquisadoras da área. In: MIRANDA, C.; AGUIAR, F.L.; PIERRÔ, M.C. (Org.). Bibliografia básica sobre relações raciais e educação. Rio de Janeiro: DP\&A, 2004.

GUIBERNAU, I.; BERDUN, M. Montserrat. Nacionalismos: o estado nacional e o nacionalismo no século XX. Trad. Mauro Gama, Claúdia Martinelli Gama. Rio de Janeiro: Jorge Zahar, 1997.

HABERMAS, Jurgen. Realizações e Limites do Estado Nacional Europeu. In:

BALAKRISHNAN, Gopal (Org.). Um mapa da questão nacional. Rio de Janeiro:

Contraponto, 2000, p. 297-310.

HOBSBAWM, E. J. Nações e nacionalismo desde 1780: programa, mito e realidade. Trad. de Maria Célia Paoli e Anna Maria Quirino, Rio de Janeiro: Paz e Terra, 3. ed. 2002.

IANNI, Octávio. Estado e planejamento econômico no Brasil (1930-1970). 2. ed. Rio de Janeiro: Civilização Brasileira, 1991.

LIMA, Antônio Vizeu da Costa. Complexos interescolares e intercomplementaridade no ensino da Amazônia. Revista de Cultura do Pará, ano 3, n. 12-13, p. 156-175, jul./dez.1973.

MICELI, Sérgio (Org.). Estado e cultura no Brasil. São Paulo: Difel, 1984.

MOTTA, Rodrigo Patto Sá. As universidades e o regime militar: cultura política brasileira e modernização autoritária. Rio de Janeiro: Zahar, 2014.

\begin{tabular}{|l|c|c|c|c|c|} 
(C) Rev. Inter. Educ. Sup. & Campinas, SP & v.3 & n.3 & p.678-705 & set./dez. 2017 \\
\hline
\end{tabular}


OLIVEIRA, Dalila Andrade. Educação básica: gestão do trabalho e da pobreza. Petrópolis: RJ: Vozes, 2000.

PARÁ, Mensagem enviada à Assembleia Legislativa - Governo Fernando José de Leão Guilhon, em 31 de março de 1970.

PARÁ. Secretaria de Estado de Educação. Plano estadual de educação: 1987-1990. BelémPará, 1987.

PETIT, Pere. Chão de promessas: elites políticas e transformações econômicas no estado do Pará pós-1964. Belém: Paka-Tatu, 2003.

PETIT, Pere. A esperança equilibrista: a trajetória do PT no Pará. São Paulo: Boitempo, 1996.

PETIT, Pere; CUÉLLAR, Jaime. O golpe de 1964 e a instauração da ditadura civil-militar no Pará: apoio e resistências. Revista Estudos Históricos, Rio de Janeiro, v. 25, n. 49, p. 169 189, jan./jun. 2012.

ROMANELLI, Otaíza de Oliveira. História da educação no Brasil (1930-1973). PetrópolisRJ: Vozes, 16. ed. 1994.

SANFELICE, José Luis. O Estado e a política educacional do regime militar. In: SAVIANI, Dermeval (Org.). Estado e políticas educacionais na história da educação brasileira. Vitória: EDUFES, 2011.

SCHWARCZ, Lilia K. Moritz. Nem preto, nem branco, muito pelo contrário: cor e raça na sociabilidade brasileira. São Paulo: Claro Enigma, 2012a.

SCHWARCZ, Lilia K. Moritz; BOTELHO, André (Org.). Cidadania, um projeto em construção: minorias, justiça e direitos. São Paulo: Claro Enigma, 2012b.

SINGER, Paul. Repartição da Renda: pobres e ricos sob o regime militar. Rio de Janeiro: Jorge Zahar Editor, 1986.

SKIDMORE, Thomas. Brasil: de Castelo a Tancredo. Rio de Janeiro: Paz e Terra, 1988.

SKIDMORE, Thomas. O Brasil visto de fora. 2. ed. Rio de Janeiro: Paz e Terra, 2001.

SHIROMA, Eneida Oto; MORAES, Maria Célia Marcondes de; EVANGELISTA, Olinda. Política educacional. 3. ed. Rio de Janeiro: DP\&A, 2004.

TELLES, Edward. O significado da raça na sociedade brasileira. Trad. Ana Arruda Callado. Princeton e Oxford: Princeton University Press, 2012.

\begin{tabular}{l|l|l|l|l} 
(C) Rev. Inter. Educ. Sup. & Campinas, SP & v.3 & n.3 & p.678-705
\end{tabular}
set./dez. 2017 


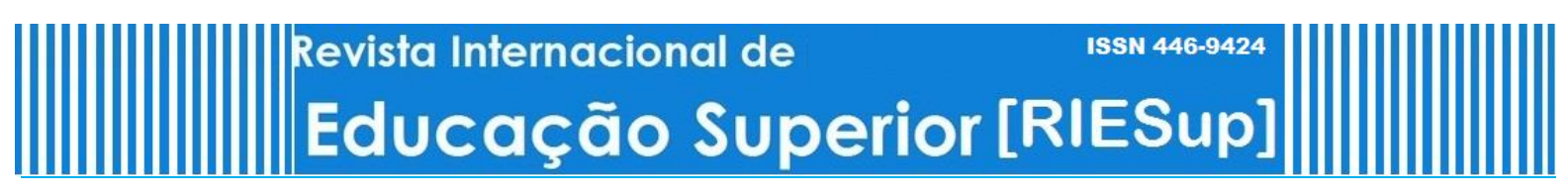

Artigo

DOI: $10.22348 /$ riesup.v3i3.7760

VIEIRA, Evaldo. A república brasileira: 1964-1984. São Paulo: Moderna, 1985.

\section{${ }^{\mathrm{i}}$ Sobre a autora}

Rosângela Maria de Nazaré Barbosa e Silva

E-mail: rosangelabarbosaesilva@gmail.com / ORCID: http://orcid.org/0000-0001-8365-8067

Universidade da Amazônia - Brasil

Doutora em Educação pela Universidade Federal do Pará [UFPA] 